\title{
Expressiness of the Main Characters of a New Genotype of White Kidney Bean
}

\author{
Ion GHERASE*, Elena BARCANU, Costel VÎNĂTORU, Ovidia AGAPIE (DOBRE), Bianca TĂNASE and \\ Geanina NEGOȘANU
}

Vegetable Research-Development Station Buzau, 23 Mesteacanului St, Romania

*corresponding author: ion2196@yahoo.com

BulletinUASVM Horticulture 77(2) / 2020

Print ISSN 1843-5254, Electronic ISSN 1843-5394

DOI:10.15835/buasvmcn-hort: 2020.0042

\begin{abstract}
Currently, in Romania there are just a few autochthonous white kidney bean varieties and this is the main reason why Vegetable Research Development Station (VRDS) Buzau has chosen a breeding program for this species. The aim of this study was to assess the main quantitative characteristic of a new cultivar of kidney beans, 'Doina'. The correlation matrix showed a strong relationship between plant height and bush diameter and also with leaf length and a negative correlation between plant height and pods mass per plant. The cultivar has a yield potential of over $3000 \mathrm{~kg} / \mathrm{ha}$ and a compact maturation of the pods, being suitable for mechanized harvesting. An important feature is plant hardiness, due to local genetic resources used in the breeding program. During the research it was found that the variety has a distinct phenotypic expressiveness with a high yield and quality potential.
\end{abstract}

Keywords: breeding, crop technology, 'Doina' cultivar, Phaseolus vulgaris, phenotype

\section{Introduction}

Beans are a member of Fabaceae family and there are about 20 leguminous species utilized as dry grain in substantial amounts for human nutrition (Costa el al., 2006; Lin et al., 2008). Phaseolus vulgaris $\mathrm{L}$. has been recognized to be domesticated and originated in America on the basis of chronological, archaeological, botanical and linguistic evidences (Gepts and Dpbouk, 1991; Papa and Gepts, 2003; Papa et al., 2005) and now is a worldwide grown plant from tropics, subtropics and temperate zone. It is recognized as 'poor man's meat' (Tharanathan and Mahadevamma, 2003), showing their importance for consumption in the third world countries where protein energy malnutrition often appear as major nutrition problem (Shimelis and Rakshit, 2005). Harlen (2018) states that beans contain a number of bioactive compounds such as phenolic substances that may play key metabolic roles in humans and/or animals that frequently consume this food. From a nutritional point of view, beans are recognized as good source of proteins, which is 2-3 times higher than in cereal grains (Siddiq et al., 2010). High dry matter content also contains high amounts of starch, dietary fiber, minerals and vitamins (Kutos et al., 2003; Costa et al., 2006). In addition to these, beans also contain rich variety of phytochemicals with antioxidant activity and an extensive array of flavonoids such as anthocyanins, proanthocyanidins, flavones, phenolic acids and isoflavones (Beninger and Hosfield, 2003; Choung et al., 2003; Aparicio-Fernadez et al., 2005; Lin et al., 2008; Granito et al., 2008).

Dry beans are the second most cultivated species after soybean, from Fabaceae family. In the world, the most cultivated areas are found in Asia, with $47.4 \%$, followed by America $26.1 \%$, Africa 23.1 and Europe 3.3\%. The countries with highest yield and area harvested in 2018 were: 
India, with 5,677,500 t, followed by Myanmar with 4,779,926 t and Brazil with 2,917,825. The world area harvested with dry bean has increased from $30,783,463$ ha in 2015 to $34,495,662$ ha in 2018 , of course, the yield also had an increase from $27,614,253 \mathrm{t}$ to $30,434,280 \mathrm{t}$ in 2018 (FAOSTAT).

Unfortunately, in Romania, the dry bean sector has known a decrease during the past years, the cultivated area in 2015 was 22,122 ha with and yield of 12,231 $\mathrm{t}$ and dropped to 19,966 $\mathrm{t}$ in 2018, but the yield was higher due to favourable pedoclimatic conditions or maybe the use of different varieties and registered a value of 17,298 $t$ (FAOSTAT).

In the present, in Romania there are just a few autochthonous white kidney beans and this is the main reason why Vegetable Research Development Station (VRDS) Buzau has chosen a breeding program for the species. The aim of this study was to assess the main quantitative characteristic of a new cultivar of kidney beans, 'Doina'.

\section{Materials and methods}

VRDS Buzau has obtained so far a number of four varieties of French beans ('Anisia', 'Clarisa', 'Ioana' and 'Menuet') and two varieties of climbing bean ('Maura 2000', 'Teodora'), all with mixed destination, pods and beans, but mainly used for pods. 'Doina' cultivar is used strictly for bean consumption. The variety was obtained by repeated individual selection and now is submitted to a preservation program. Throughout the vegetation period, biometric and phenological observations were made with an emphasis on the main characters of the plants. The descriptors used were the one from UPOV guidelines. Morphophysiological descriptors used were: leaf colour, plant height (PH), bush diameter (BD), length (LL) and width (LW) of leaves, petiole length (PeL) flower colour, pod thickness (PT), length (PL) and width (PW), number of pods per plant (NPP), number of grains in a pod (NGP), grain colour, grain length (GL), width and thickness (GT), pod mass and mass of pods/plant (MPP). The qualitative characters were noted based on visual evaluation while the quantitative traits were counted, measured using metric rulers, caliper and weighed using weighing balance. For all agromorphological features, descriptive statistics were calculated, including Analysis of Variance (ANOVA) and Pearson correlation coefficient, adopting the statistical software XLSTAT. Means comparison were performed by Duncan test.

During a period of two years (2018-2019) phenological descriptors were tracked such as: sowing date, sprouting date, date of trifoliate leaves, date of flowering, date of first pod and date of harvest. The planting scheme used was 70 $\mathrm{cm}$ between rows and $20 \mathrm{~cm}$ between plants in a row. The seeds were sown in the second decade of May. A randomized blocks design with three replications was used.

\section{Results and discussions}

The analysis of climatic condition of 20182019 (Tab. 1) showed variation in comparison with the multiannual mean, it was noticed that rainfall was higher in 2019, and the mean monthly temperatures were also higher in 2019 than multiannual temperature while in 2018, the mean temperatures and sum of rainfalls were a bit lower than the multiannual mean.

Phaseolus vulgaris has a weakly developed root with Rhizobium nodosities. The mean values of plant characteristics are presented in Table 2. The plant height of 'Doina' cultivar varies from

Table 1. Climatic conditions during the vegetation period of 2018-2019

\begin{tabular}{lcccc}
\hline \multicolumn{1}{c}{ Temperatures/rainfall } & May & June & July & August \\
\hline Mean monthly temperatures $\left({ }^{\circ} \mathrm{C}\right) 2019$ & 22.5 & 27 & 30 & 29.5 \\
\hline Mean monthly temperatures $\left({ }^{\circ} \mathrm{C}\right) 2018$ & 22 & 25 & 28 & 30 \\
\hline Multiannual monthly temperature $\left({ }^{\circ} \mathrm{C}\right)$ & 23 & 26 & 29 & 29 \\
\hline Sum of rainfall $(\mathrm{mm}) 2019$ & 71 & 92 & 75 & 53 \\
\hline Sum of rainfall $(\mathrm{mm}) 2018$ & 65 & 83 & 64 & 50 \\
\hline Multiannual mean of rainfall $(\mathrm{mm})$ & 68 & 84 & 65 & 51 \\
\hline
\end{tabular}


33.1 to $46.3 \mathrm{~cm}$ with an average bush diameter of $33.8 \mathrm{~cm}$. The first primary leaves have oval shape and the other leaves are trifoliate with a green medium colour. The length of leaves varies between 18.8-21.2 $\mathrm{cm}$ and a mean width of 18.6 $\mathrm{cm}$. The flower colour is white and the pod colour is green, with slight porosity when young and smooth at physiological maturity.

Table 2. Mean values of plant characteristics

\begin{tabular}{lc}
\hline \multicolumn{1}{c}{$\begin{array}{c}\text { Plant } \\
\text { characteristics }\end{array}$} & $\begin{array}{c}\text { Value } \pm \text { Standard } \\
\text { deviation }\end{array}$ \\
\hline Plant height $(\mathrm{cm})$ & $39.6 \pm 6.50$ \\
\hline Bush diameter $(\mathrm{cm})$ & $33.8 \pm 4.85$ \\
\hline Petiol length $(\mathrm{cm})$ & $2.4 \pm 0.17$ \\
\hline Foliole length $(\mathrm{cm})$ & $19.9 \pm 1.49$ \\
\hline Foliole width $(\mathrm{cm})$ & $18.6 \pm 1.20$ \\
\hline Pod length $(\mathrm{cm})$ & $12.03 \pm 0.37$ \\
\hline Pod width (cm) & $1.36 \pm 0.05$ \\
\hline Pod thickness (cm) & $0.94 \pm 0.15$ \\
\hline Number of grains/pod (pcs) & $6 \pm 0.57$ \\
\hline Grain length (cm) & $1.22 \pm 0.1$ \\
\hline Grain thickness (cm) & $0.76 \pm 0.05$ \\
\hline Number of pods/plant (pcs) & $26 \pm 2.88$ \\
\hline Mass of pods/plant (g) & $48.89 \pm 2.95$ \\
\hline
\end{tabular}

The average length of pods is $12.03 \mathrm{~cm}$, with a mean width of $1.36 \mathrm{~cm}$ and an average thickness of $0.94 \mathrm{~cm}$. Number of pods per plant varies between 23-28 pods, and the number of grains in a pod is six. The grain is white with a mean length of 1.22 $\mathrm{cm}$, an average diameter of $0.76 \mathrm{~cm}$. The mass of pods/plant has an average value of $48.89 \mathrm{~g}$. The grains are easy to be boiled, are buttery and have a specific aroma. Yield potential is over $3000 \mathrm{~kg}$ grains/ha. Due to compact maturation of pods, the variety is suitable for mechanized harvesting and one important characteristic is that pods are easily to unfold. A valuable feature is plant hardiness, due to local genetic resources used in the breeding program. It can be cultivated in organic systems. In Figure 1 are presented crop details of 'Doina' cultivar.

In order to establish a relationship between the main characters a correlation matrix (Pearson) was made (Tab. 3). It can be observed that there is a strong correlation among plant height and bush diameter and also with leaf length and a negative correlation between plant height and mass of pods per plant. Positive correlations are through bush diameter, petiol length, pod weight, grain thickness and number of grains per pod; but also a strong negative correlation amongst bush diameter and mass of pods per plant. Pod mass per plant has a negative correlation with petiol length and with characteristics of pods as grain thickness and width. Petiol length has a strong correlation between grain thickness and pod width and also a negative correlation with number of grains per plant. Pod length is strongly correlated with pod thickness and pod thickness with grain length. Similar studies regarding the correlation of pod length with pod thickness was also found in bean varieties from Turkey (Madakbas and Ergin, 2011).

Number of grains in a pod has a negative correlation with grain thickness and pod width. Number of pods per plant has a strong negative correlation with leaf length. The significant posi-
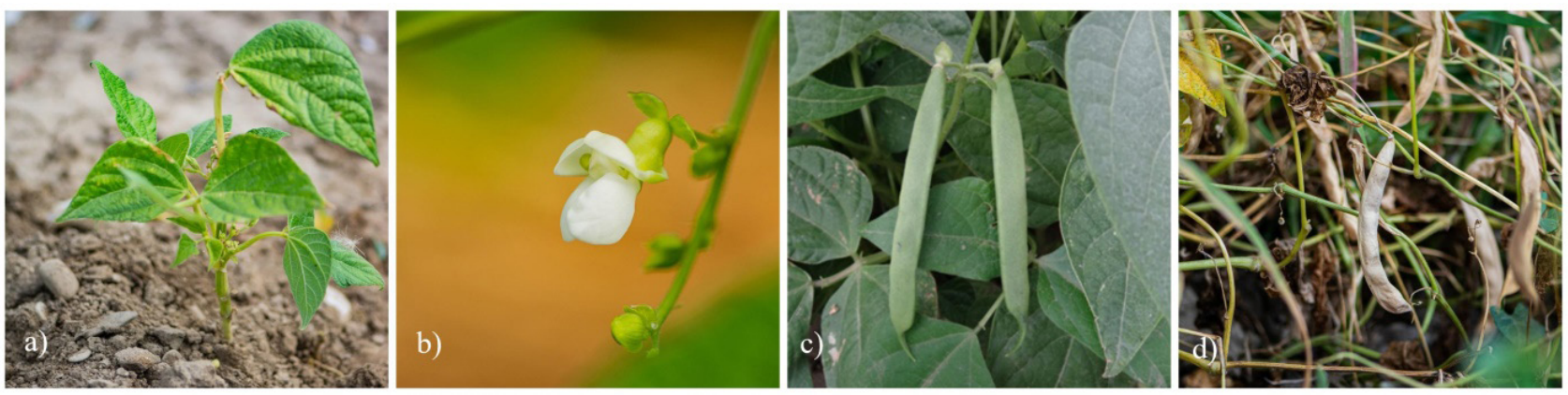

Figure 1. Plant details: a) First true leaves b) Flowers of bean c) Bean pods d) Dry bean pods 
Table 3. Correlation matrix of main characters

\begin{tabular}{|c|c|c|c|c|c|c|c|c|c|c|c|c|c|}
\hline Variable & NPP & LL & PH & MPP & BD & PeL & GT & PW & NGP & LW & PL & PT & GL \\
\hline NPP & 1 & & & & & & & & & & & & \\
\hline LL & -0.983 & 1 & & & & & & & & & & & \\
\hline PH & -0.850 & 0.928 & 1 & & & & & & & & & & \\
\hline MPP & 0.752 & -0.853 & -0.986 & 1 & & & & & & & & & \\
\hline $\mathrm{BD}$ & -0.658 & 0.776 & 0.955 & -0.991 & 1 & & & & & & & & \\
\hline PeL & -0.499 & 0.638 & 0.879 & -0.946 & 0.981 & 1 & & & & & & & \\
\hline GT & -0.493 & 0.636 & 0.877 & -0.944 & 0.978 & 0.998 & 1 & & & & & & \\
\hline PW & -0.493 & 0.636 & 0.877 & -0.944 & 0.978 & 0.998 & 1.000 & 1 & & & & & \\
\hline NGP & 0.494 & -0.601 & -0.829 & 0.893 & -0.925 & -0.943 & -0.917 & -0.917 & 1 & & & & \\
\hline LW & 0.000 & -0.167 & -0.523 & 0.658 & -0.751 & -0.866 & -0.864 & -0.864 & 0.816 & 1 & & & \\
\hline PL & -0.608 & 0.469 & 0.106 & 0.061 & -0.193 & -0.381 & -0.380 & -0.380 & 0.361 & 0.792 & 1 & & \\
\hline $\mathrm{PT}$ & 0.757 & -0.630 & -0.299 & 0.138 & -0.007 & 0.187 & 0.196 & 0.196 & -0.132 & -0.649 & -0.971 & 1 & \\
\hline GL & -0.864 & 0.770 & 0.477 & -0.324 & 0.196 & 0.000 & 0.000 & 0.000 & 0.000 & 0.500 & 0.924 & -0.973 & 1 \\
\hline
\end{tabular}

Note: Values in bold are significant at $\mathrm{p} \leq 0.05$, according to Duncan test

tive correlation between number of grain per plant and leave width indicates that these characters are efficient in yield determination. In studies of Okii et al. (2014) and Loko et al. (2018) similar findings were reported.

As phenological observations are concerned, it was noticed that under conditions of 20182019 the sprouting emerged after 13-17 days and the appearance of the first trifoliate leaf was 1722 days after sowing. The first flowers arose in 43-48 days and first pod in a period of 54 days, in average. The harvest was after 100-110 days after sowing. The phenological characteristics are affected greatly by environmental conditions.

\section{Conclusions}

The researches have been completed so far with obtaining of a new variety of beans that has been registered in the Official Catalogue of Species and Varieties of Cultivated Crops under the name 'Doina'. The variety has a distinct phenotypic expressiveness with a high yield and quality potential.

Acknowledgments. The work was supported by a grant of the Romanian Ministry of Research and Innovation, CCCDI - UEFISCDI, project number PN-III-P1-1.2-PCCDI-2017/ contract 28 PCCDI /2018, within PNCDI III..

\section{References}

1. Aparicio-Fernandez $\mathrm{X}$, Yousef GG, Loarca-Pina G, Gonzalez de Mejia E, Lila MA (2005). Characterization of polyphenolics in the seed coat of black jamapa bean (Phaseolus vulgaris L.). J. Agric. Food Chem., 53: 46154622.

2. Beninger CW, Hosfield GL (2003). Antioxidant activity of extracts, condensed tannin fractions, and pure flavonoids from Phaseolus vulgaris L. seed coat color genotypes. J. Agric. Food Chem., 51: 7879-7883.

3. Choung MG, Choi BR, An YN, Chu YH, Cho YS (2003). Anthocyanin profile of Korean cultivated kidney bean (Phaseolus vulgaris L.). J. Agric. Food Chem., 51: 70407043.

4. Costa GEA, Queiroz-Monici KS, Reis SMPM, Oliveira AC (2006). Chemical composition, dietary fibre and resistant starch contents of raw and cooked pea, common bean, chickpea and lentil legumes.

5. FAOSTAT statistics. http://www.fao.org/faostat/en/\#home

6. Gepts P, Dpbouk D (1991). Origin, domestication, and evolution of the common bean (Phaseolus vulgaris L.). Common beans: Research for Crop Improvement, Van Schoonhoven, A. and Voyset, O. (Eds), Wallingford, England: CAB International, pp: 7-53.

7. Granito M, Palolini M, Perez S (2008). Polyphenols and antioxidant activity of Phaseolus vulgaris stored under extreme conditions and processed. LWT 41: 994-999.

8. Harlen WC, Jati IRA (2018). Antioxidant Activity of Anthocyanins in Common Legume Grains. In Polyphenols: Mechanisms of Action in Human Health and Disease, Academic Press, pp. 81-92.

9. Kutos T, Golob T, Kac M, Plestenjak A (2003). Dietary fibre content of dry and processed beans. Food Chem,. 80: 231235. 
10. Lin LZ, Harnly JM, Pastor-Corrales MS, Luthria DL (2008). The polyphenolic profiles of common beans (Phaseolus vulgaris L.). Food Chem., 107: 399-410.

11. Loko LEY, Orobiyi A, Adjatin A, Akpo J, Toffa J, Djedatin G, Dansi A (2018). Morphological characterization of common bean (Phaseolus vulgaris L.) landraces of Central region of Benin Republic. Journal of Plant Breeding and Crop Science, 10(11): 304-318.

12. Madakbaş SY, Ergin M (2011). Morphological and phenological characterization of Turkish bean (Phaseolus vulgaris L.) genotypes and their present variation states. African Journal of Agricultural Research, 6(28): 6155-6166.

13. Okii D, Tukamuhabwa $\mathrm{P}$, Odong $\mathrm{T}$, Namayanja $\mathrm{A}$, Mukabaranga J, Paparu P, Gepts P (2014). Morphological diversity of tropical common bean germplasm. African Crop Science Journal, 22(1): 59-67.

14. Papa R, Acosta J, Delgado-Salinas A, Gepts P (2005). A genome-wide analysis of differentiation between wild and domesticated Phaseolus vulgaris from Mesoamerica. Theor. Appl. Genet., 111: 1147-1158.

15. Papa R, Gepts P (2003). Asymmetry of gene flow and differential geographical structure of molecular diversity in wild and domesticated common bean (Phaseolus vulgaris L.) from Mesoamerica. Theor. Appl. Genet., 106: 239-250.

16. Shimelis EA, Rakshit SK (2005). Proximate composition and physico-chemical properties of improved dry bean (Phaseolus vulgaris L.) varieties grown in Ethiopia. LWT, 38: 331-338.

17. Siddiq M, Ravi R, Dolan KD (2010). Physical and Functional Characteristics of Selected Dry Bean (Phaseolus vulgaris L.) flour. LWT-Food Sci Technol., 43: 232-237.

18. Tharanathan RN, Mahadevamma S (2003). Grain legumes-a boon to human nutrition. Trends Food Sci. Technol., 14: 507-518. 